\title{
FACTORS INFLUENCING THE LEVEL OF TAX LITERACY of Students of Bachelor Study Programmes IN ECONOMICS AT FACULTIES OF ECONOMICS
}

\section{Lucie Formanová ${ }^{1}$, Michal Mádr $^{2}$, Břetislav Andrlík ${ }^{3}$, Veronika Hrabalová ${ }^{4}$}

\begin{abstract}
The paper is devoted to the issue of tax literacy, where the aim is to identify factors that affect the level of tax literacy of students of economics at the bachelor's degree level in the Czech Republic. Through a questionnaire survey, students' knowledge was tested and research hypotheses were verified using statistical and econometric methods. The survey showed that the level of tax literacy of the defined sample of respondents was satisfactory. Moreover, it was found that this knowledge is mainly influenced by the factor of taking courses with a focus on tax issues and the respondent's own perception of the level of tax literacy. Specifically, respondents who had taken a tax course or considered themselves tax literate had, on average, five percentage points higher scores on the tax literacy test. On the other hand, the gender of the respondent can be considered a statistically insignificant factor.
\end{abstract}

\section{Keywords}

Tax Literacy, Bachelor Students, Economic Studies

\section{Introduction}

In general, literacy can be understood as an individual's ability to read, write and count that is usually acquired in an individual's early years of primary school (Průcha, Walterová and Mareš, 2013). However, Rabušicová (2002) adds that nowadays literacy is not only

\footnotetext{
${ }^{1}$ Mendel University in Brno, Zemědělská 1, 61300 Brno, Czech Republic.

E-mail: lucie.formanova@mendelu.cz.

${ }^{2}$ Mendel University in Brno, Zemědělská 1, 61300 Brno, Czech Republic.

E-mail:michal.madr@mendelu.cz.

${ }^{3}$ Mendel University in Brno, Zemědělská 1, 61300 Brno, Czech Republic.

E-mail: bretislav.andrlik@mendelu.cz.

${ }^{4}$ Mendel University in Brno, Zemědělská 1, 61300 Brno, Czech Republic.

E-mail:xhrabal6@node.mendelu.cz.
} 
understood as the ability to read, write or count, but in recent decades, new insights into the meaning of this concept have emerged, with Bertl (2016) stating that the education system should be set up to best prepare individuals for the conditions of the contemporary world. Therefore, in the 1970s, the concept of functional literacy began to emerge, which can be considered as a higher level of literacy that consists in an individual's ability to process textual information, expand his or her knowledge or develop his or her potential (Doležalová, 2005; Gavora, 2002). Functional literacy consists of three components, namely textual, documentary and numeracy (Doležalová, 2005). Pavelková, Knaifl and Preuss (2012) add financial literacy as another important component. According to Noveský and Balabán (2009), financial literacy grows in importance as society evolves, as financial markets, products and the means of payment themselves are constantly evolving. Financial literacy is also an important topic for the OECD, which, as part of the PISA project, assesses the level of knowledge of 15-year-old pupils, not only in the area of financial literacy, but also assesses knowledge in subjects that are compulsory in school. For example, in 2012, Czech pupils achieved above-average results, ranking among the top seven OECD countries in terms of financial literacy (Czech School Inspectorate, 2014). The importance of financial literacy is therefore also perceived by the Czech Republic that was one of the first countries in the world to introduce financial education for primary and secondary school pupils in 2009 (MoF ČR, 2014). In addition, a national strategy on financial education, the "National Financial Education Strategy 2.0", was approved in January 2020, targeting seniors, educators, and public sector employees, in addition to the aforementioned groups (MoF ČR, 2020). A subset of financial literacy can also include tax literacy (Cvrlje, 2015). However, it should be noted that tax literacy surveys are not a very common research topic, as confirmed by Bornman and Wassermann (2018). However, the importance of this issue is highlighted by Blechová and Sobotovičová (2013), who argue that tax knowledge not only determines the standard of living of the population, their financial stability, but also helps to make the right decisions in the area of family, personal and business finances. Moreover, a sufficiently educated population is important not only for the individuals themselves, but also for the country as a whole. For example, Eriksen and Fallan (1996) point out that educated citizens are aware of the risks of not meeting their tax obligations. Bornman and Wassermann (2018) found through empirical investigation that taxpayer knowledge is then a key factor in relation to tax compliance. Subsequently, Kurniawan (2020) also found through regression analysis that tax education has a positive effect on taxpayer compliance. The OECD (2015) points out the same in its publication "Building Tax Culture" and therefore encourages member states to invest more in taxpayer education, as only an educated taxpayer knows what the functions of taxes are and what taxes are for, which in turn has an impact on the level of taxpayer morale, as confirmed, among others, by the study of Bahari and Ling (2009). Cvrlje (2015) further highlights the reality of tax illiteracy, which not only threatens the country's economy, but especially the individual's available financial resources. Bhushan and Medury (2013) define tax literacy as an individual's knowledge and their ability to apply it to issues related to taxation. According to the authors, every taxpayer should be able to calculate their tax liability using institutes that can optimise their tax liability. Of course, the ability to file 
a proper claim and comply with your tax obligations is also essential. This is where tax literacy becomes more important. Tax ignorance can be very detrimental to the individual, as he or she does not know what options he or she has in determining tax liability, such as tax credits, deductible items from the tax base or non-taxable amounts of the tax base. The taxpayer either does not use the items at all, thus paying more tax than his actual tax liability, or is forced to incur additional costs in the form of payments to tax advisers. The complexity and increasing additional costs will become even more important as countries begin to digitise their tax administration, putting pressure on taxpayer autonomy in meeting their tax obligations. Kolbenhayerová and Křižová (2021) offer an important argument for intensifying the digitalisation of public administration, stating that digitalisation can reduce administrative costs caused by communication between the public administration and the individual by up to 15 to $20 \%$, which at a time of tight budgets caused by the COVID-19 pandemic, can mean significant savings. The measurement of administrative costs in the Czech Republic was addressed by Andrlík (2015). Digitalisation of taxes will also contribute to more efficient tax collection or the fight against tax fraud. For this reason, a high level of tax literacy is also desirable from the point of view of the state, as the gradual pressure for the electronisation of state administration is inevitable. The importance of tax knowledge in relation to the digitalisation of taxation and new areas of taxation is also highlighted by Bornman and Wassermann (2020), whose research objective was to identify the tax knowledge requirements of taxpayers in three categories (general, procedural and legal) so that the individual can function in the new digital economy, which according to Bornman and Wassermann (2020) is increasingly associated with information and communication technologies. The legal requirements are understood as an understanding of the legislation, the procedural requirements include the ability to comply with tax obligations and the general requirements consist of the ability to understand the meaning of taxes and their functions. Moreover, understanding the requirement for taxpayer knowledge can also have a significant impact for tax administrators facing the risks of tax fraud or other threats arising from the ignorance of taxpayers whose level of tax literacy is unsatisfactory. Finally, Bornman and Wassermann (2020) present the risks faced by e-government in the field of taxation. Among the general risks, these authors highlight the lack of taxpayer awareness of the functions of taxes or uncertainties regarding the way transactions are reported. In terms of procedural risks, they point to taxpayers' insufficient knowledge of ICT or unsatisfactory records, while threats arising from the legal environment include ignorance of tax legislation, e.g. in the form of an individual's lack of knowledge of whether or not they are becoming a taxpayer, whether they are taxing the subject of the tax in the correct manner and in the correct jurisdiction, or applying the correct amount of deductible items. An example of the digitalisation of taxes can be found, for example, in Malaysia, where the "Self-Assessment System" was implemented to modernise the tax collection system and make it more efficient. Therefore, the obligation and responsibility for calculating the tax liability, including filing the tax return, has been shifted to taxpayers. The pressure for increasing levels of taxpayer tax literacy is evident here (Halim, Ahmad, Katmun and Jaafar, 2015), as confirmed by Latiff, Noordin, Omar and Harjito (2005). On the European continent, the UK government has taken the decision 
to digitise tax and the tax system through the "Making Tax Digital" programme, with the main aim of streamlining and simplifying tax administration (GOV.UK, 2020). It is clear from the programme presented that the plan is based on a fundamental principle, and that is taxpayer education. For this reason, an educational programme was created to educate primary school pupils (Alexander, Balavac, Mukherjee, Lymer and Massey, 2018). In 2018, a survey was carried out among students at two UK universities to find out the current state of tax knowledge and morale among students entering the labour market. The results of the survey did not yield positive results, as significant gaps in students' tax knowledge were found. In conclusion, the authors recommend the inclusion of tax issues in the curriculum of all secondary schools, regardless of whether students plan to continue their studies at university or not. Berhane (2011) further points out that tax education should be given more attention by the government and the Ministry of Education and therefore tax education should be implemented in all university curricula and there should be better taxpayer awareness in general. Therefore, Kasipillai, Aripin and Amran (2003) suggest that universities should provide basic information materials on taxation to all students. The aim of these policies is to increase students' tax awareness and thus their level of tax literacy (Kurniawan, 2020). The apparent positive effect of tax education in secondary education on increasing taxpayer tax literacy has been identified in research by Kurniawan (2020) or Palil and Mustapha (2011) who also find that a higher level of tax knowledge has a significant effect on taxpayer compliance. To this, Latiff, Noordin, Omar and Harjito (2005) add that it is certainly important to promote taxpayer education, but it is also necessary for taxpayers themselves to show an interest in tax knowledge. Based on the trends described above, it is clear that tax literacy will become increasingly important in the 21 st century, primarily because of the pressure to implement e-government, which is becoming an increasingly hot topic in the COVID-19 pandemic.

The issue of tax literacy can be viewed from many perspectives, so the following part of the paper provides an overview of the research already conducted on the topic, which will serve as a basis for determining research hypotheses.

In the Czech Republic, the issue of tax literacy was addressed by Blechová and Sobotovičová (2013), who examined the level of tax literacy among students at the School of Business Administration in Karviná. The target group included students of bachelor study programmes in economics and follow-up master study programmes, in full-time and combined form of study. The research investigated the level of tax literacy of a selected segment of students and, in addition, addressed the research question of whether the level of tax knowledge of students depends on the form of study. This research investigation was carried out with a defined sample of students who entered a given level of study, i.e. before studying tax-oriented subjects. The authors concluded that more than half of the students have minimal or insufficient knowledge in the field of taxation, which can be described as an unsatisfactory result and an alarming finding from the point of view of the target group. Moreover, it was found that students of the combined form of study show a higher level of tax literacy than students of the full-time form. However, this result was not surprising to the authors, as students of the combined form of study tend to be in contact with practice, and their knowledge thus stems from their practical experience. 
Two years later, the same authors decided to carry out a second research investigation to test whether students' knowledge improves after taking courses on tax issues. Thus, the authors conducted the questionnaire survey at two points in time, namely when the students started their studies and subsequently after the students had completed the tax courses. Based on the results obtained, the authors concluded that taking a tax course has an impact on the level of tax literacy of students. (Sobotovičová and Blechová, 2015).

Moučková and Vítek (2018) also focused on students of economically oriented disciplines and analysed the level of tax literacy of students of the University of Economics in Prague in the area of personal income tax and value added tax. Like Sobotovičová and Blechová (2015), they focused on whether the level of tax literacy is affected by whether a student has taken a tax course or has practical experience. The authors' results show that the level of personal income tax literacy depends on whether a student has filed a tax return in the past. In the area of value added tax, it was found that the level of knowledge depends on whether the student has taken the course "Taxation of Consumption", but it does not depend on whether the student has filed a tax return in the past.

Furthermore, Paseková, Kovařík and Ředinová (2013), who investigated the level of tax literacy among students of non-economically oriented majors at Tomas Bata University in Zlín. In addition to tax literacy, the authors measured whether the respondent considered himself or herself tax literate before and after the test. In addition, they investigated whether the respondent's judgement of their level of tax literacy was consistent with their test score. The results show that students who rated themselves as tax literate before taking the test confirmed this statement in the test, which also suggests that students are able to objectively assess their knowledge. Finally, the authors conclude that the level of non-economically oriented students was satisfactory for a selected segment of respondents.

Tax literacy is also addressed abroad, for example in Norway Eriksen and Fallan (1996) carried out an empirical study on the impact of tax knowledge on attitudes towards taxation, i.e. tax evasion or tax justice. The authors conducted a quasi-experiment consisting of preand post-testing. The first part of the experiment involved all first-year students taking the same courses; the second part of the experiment involved students subsequently choosing an elective course (either marketing or tax law). The group of students who chose marketing was considered the control group. The results of the pre-test showed no significant differences between the two groups of respondents, but the results of the post-test revealed a significantly higher level of tax literacy among students who had taken courses focused on tax law. In addition, the authors point out that this group of respondents has also changed its view of tax ethics and tax fairness. Thus, they conclude by highlighting the fact that higher tax literacy of taxpayers can eliminate the incidence of tax evasion and therefore tax education should be included in the social sciences taught in schools. Fallan (1999) subsequently extended his research investigation to include the effect of tax knowledge on tax morale, which he examined by student gender. Men were found to have higher tax knowledge, while women, on the other hand, showed a higher level of tax morale. The research conducted by Eriksen and Fallan (1996) was inspired by Alexander, Balavac, Mukherjee, Lymer and Massey (2018), who investigated the level of tax literacy and morale among UK students, taking into account their gender, 
age, occupation, practical tax experience or tax return filing. The results showed the same conclusion as Fallan (1999), namely that women have a higher level of tax morale. However, research surveys offer verification of various factors that may influence the level of tax literacy. For example, Halim, Ahmad, Katmun and Jaafar (2015) tested whether the type of university (private vs public) affects the level of tax literacy among students in Malaysia. However, the testing did not reveal any significant differences in the knowledge of private and public university students. As a final recommendation, however, the authors mentioned the idea of incorporating tax education into the curricula of all universities in the country, as these students are the ones who become potential taxpayers and should have basic tax knowledge. Further, Bhushan and Medury (2013) examined the determinants such as nature of employment, location of workplace and level of education. All three determinants had a significant impact on the level of tax literacy of Indian citizens, with higher levels of tax literacy identified among respondents working in the government, those working in urban areas, and taxpayers who had attained tertiary education. Overall, the standard of Indian citizens was rated as below average and hence the government was advised to be more involved in disseminating information regarding taxation.

Based on the above ideas, it follows that the topic of tax literacy is a neglected topic in terms of research surveys. However, tax literacy is becoming more and more important, especially due to the pressure for computerisation and digitalisation of tax administration, which is inevitable in the current world conditions (the COVID-19 pandemic). This is confirmed by Kolbenhayerová and Křŕžová (2021) who examined the impact of digitalization on tax administration in the Czech Republic. The authors state that the current system of digitalization of the state administration is insufficient, which they argue that in 2018, for example, only $26 \%$ of individuals used the possibility of communicating with the tax administrator electronically. So the question is, what is the cause of this? One of the reasons why, for example, personal income tax payers do not use this option may be the level of their tax literacy.

The aim of the paper is to identify factors influencing the level of tax literacy of bachelor students at economically oriented universities in the Czech Republic. The segment of students of economically oriented universities was chosen deliberately because this sample of respondents should, according to general assumptions, show a higher level of tax literacy than students of non-economically oriented universities. The following hypotheses based on the literature search and research on this topic will be tested in order to fulfil the above objective:

* Hypothesis 1: Tax literacy is higher among men than women. (Fallan, 1999)

* Hypothesis 2: Tax literacy is higher among students who consider themselves tax literate. (Paseková, Kovařík and Ředinová, 2013)

* Hypothesis 3: Tax literacy is higher for students who have taken a tax course. (Blechová and Sobotovičová, 2013; Moučková and Vítek, 2018)

* Hypothesis 4: Tax literacy is higher among students who have experience in accounting and tax jobs. (Sobotovičová and Blechová, 2015)

* Hypothesis 5: Tax literacy is higher among students who have experience in filing tax returns. (Moučková and Vítek, 2018) 


\section{Materials and Methods}

The fulfilment of the research objective will be achieved through quantitative research, specifically a questionnaire survey. The target group of respondents were students of bachelor study programmes of economically oriented faculties in the Czech Republic. The author's team contacted respondents from seven universities, namely the following universities, through the study and PR departments of the universities and social networks: Mendel University in Brno, Masaryk University, Brno University of Technology, Private University of Economics in Znojmo, Tomas Bata University in Zlín, Technical University of Ostrava and Prague University of Economics and Business. Data collection was carried out between October and November 2020. The questionnaire was divided into three parts, where in the first part knowledge questions were asked to determine the level of tax literacy of the respondent, the second part of the questionnaire was devoted to determining the respondents' attitudes towards taxes and the final part of the questionnaire contained sociodemographic questions. The questionnaire items included test questions, which were used to test knowledge, as well as scaled and open-ended questions measuring respondents' preferences and attitudes towards taxes. A total of 327 respondents took part in the questionnaire survey, 283 respondents studying in the full-time form of study and 44 in the combined form. Given the low number of students in the combined form and the fact that the results of this group of students differed significantly from those of full-time students (for example, because of their work experience), only the results obtained from full-time students are analysed in the following sections.

This paper examines the factors influencing the level of tax literacy of a selected group of respondents. For this reason, only the first and third parts of the questionnaire survey are discussed below. Tax literacy (TaxLiteracy) is expressed as a percentage of the test result (respondent's pass rate). The test consisted of twenty questions, four on general taxation, eleven on direct taxation and five on indirect taxation. The success rate on the test ranges from 25 to $90 \%$ with an average of $59 \%$. The distribution of individual results is shown in the following histogram (Figure 1), in which the values are divided into ten groups. The $Y$-axis expresses the number of observations. We can identify that the analysed dataset has a negative skewness, as $65 \%$ success rate was most often achieved.

Based on a literature search and a questionnaire survey, the effect of five variables, gender (Sex), self-perceived level of tax literacy (TaxLiteracyOpinion), completion of a taxfocused course (TaxSubject), work experience in the tax field (TaxWork), and tax return filing experience (TaxReturn) is analysed. To these five factors is added one group of conditioning influences, which is made up of each year of bachelor study (StudyYear). The individual variables and their relative frequencies are shown in Table 1. At the same time, it should be added that the questionnaire does not allow to include the influence of the respondents' nationality, type or type of university due to the small number of observations. 
Figure 1: Tax Literacy - data distribution

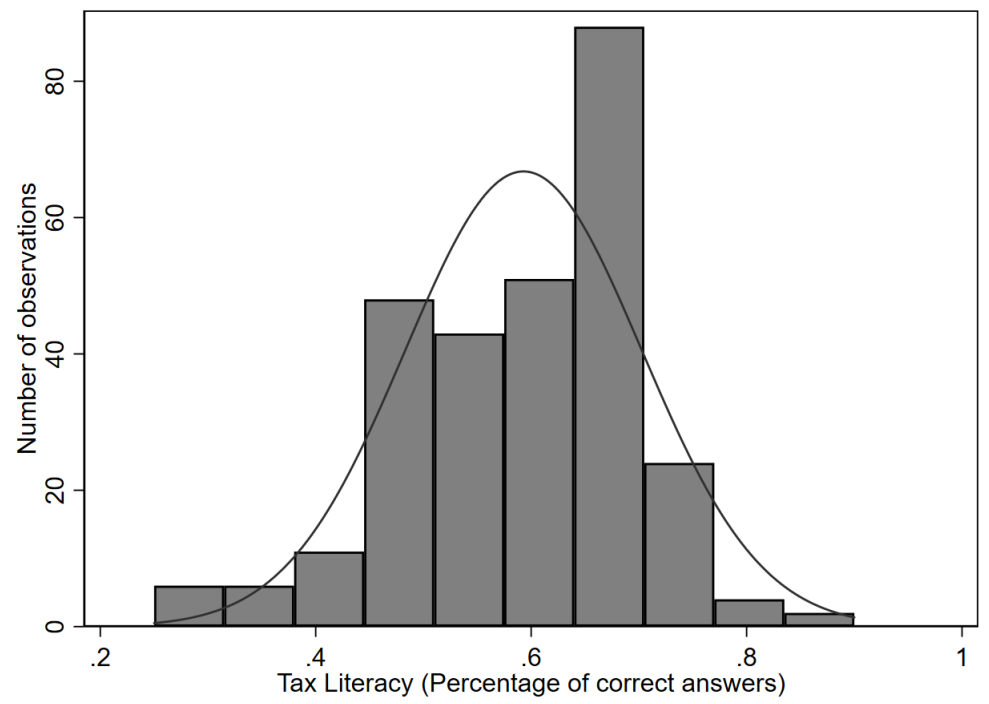

Source: own work

Table 1: Overview of the variables studied

\begin{tabular}{|l|l|ccc|}
\hline \multicolumn{1}{|c|}{ Variable } & \multicolumn{1}{|c|}{ Question } & $\begin{array}{c}\text { Answer } \\
\text { options }\end{array}$ & $\begin{array}{c}\text { Dummy } \\
\text { value }\end{array}$ & $\begin{array}{c}\text { Relative } \\
\text { frequency [\%] }\end{array}$ \\
\hline Sex & & Male & 1 & 22,97 \\
& & Female & 0 & 77,03 \\
\hline TaxLiteracyOpinion & Do you consider & Yes & 1 & 59,72 \\
& yourself tax literate? & No & 0 & 40,28 \\
\hline TaxSubject & Have you taken any & Yes & 1 & 71,38 \\
& tax courses? & No & 0 & 28,62 \\
\hline TaxWork & Do/did you work in the field & Yes & 1 & 16,96 \\
& of accounting and tax? & No & 0 & 83,04 \\
\hline TaxReturn & Do you have previous experience & Yes & 1 & 53,36 \\
& of filing a tax return? & No & 0 & 46,64 \\
\hline StudyYear & & 1st year & 1 & 31,45 \\
& & 2nd year & 2 & 60,42 \\
& & 3rd year & 3 & 32,86 \\
& & Extension & 4 & 6,71 \\
& & of studies & & \\
\hline
\end{tabular}

Source: own work 
The fulfilment of the aim of the paper is realized using two methods. First, two basic statistical tests are used and then regression analysis is performed. The paper uses a parametric two-sample t test with equal variances and a non-parametric Pearson's chisquared test. Both tests have the null hypothesis that there is no statistically significant difference between groups of respondents, i.e. that individual characteristics do not affect tax literacy. These two tests were chosen for three reasons. First, these are the most commonly used tests for this type of processed data. Second, this is due to the structure of the data, where the Tax Literacy variable does not have a normal distribution (see Figure 1), but at the same time there is a larger number of observations (283). Third, this procedure guarantees the robustness of the results.

In the second part of the Results chapter, the influence of each of the observed factors is analysed. This effect is quantified through regression analysis using the OLS method. Given the structure of the data, it was tested whether the variance of the values is homogeneous (Breusch-Pagan/Cook-Weisberg test for heteroskedasticity). The explained variable is the percentage of success in the questionnaire test (TaxLiteracy), while the explanatory variables are Sex, TaxLiteracyOpinion, TaxSubject, TaxWork and TaxReturn. In addition to the total number of respondents, the regression analysis is also performed for each year of bachelor study (StudyYear). Formally, we can write the resulting regression equation in the following way:

$$
\begin{aligned}
\text { TaxLiteracy }_{i} & =\beta_{0}+\beta_{1} \text { Sex }_{i}+\beta_{2} \text { TaxLiteracyOpinion }_{i}+\beta_{3} \text { TaxSubject }_{i}+ \\
& +\beta_{1} \text { TaxWork }_{i}+\beta_{5} \text { TaxReturn }_{i}+\epsilon_{i}
\end{aligned}
$$

\section{Results}

The chapter is divided into two parts, first the results of the statistical tests are presented and then the results of the regression analysis are presented. As mentioned in the previous section, the statistical difference between the different groups of respondents is tested using Two-sample t test with equal variances and Pearson's chi-squared. The presentation of the results is complemented by box plots for each variable (Figure 2). Statistical and graphical outputs suggest to us that there is no gender difference in tax literacy, while variables representing self-perceived tax literacy, completion of a tax course, and work experience in the tax field could explain the different levels of tax literacy. In the case of the tax filing experience, the results suggest that there might be an effect, but the outcomes are not as unambiguous as for the previous factors. 
Figure 2: Tax Literacy and differences between different groups of respondents

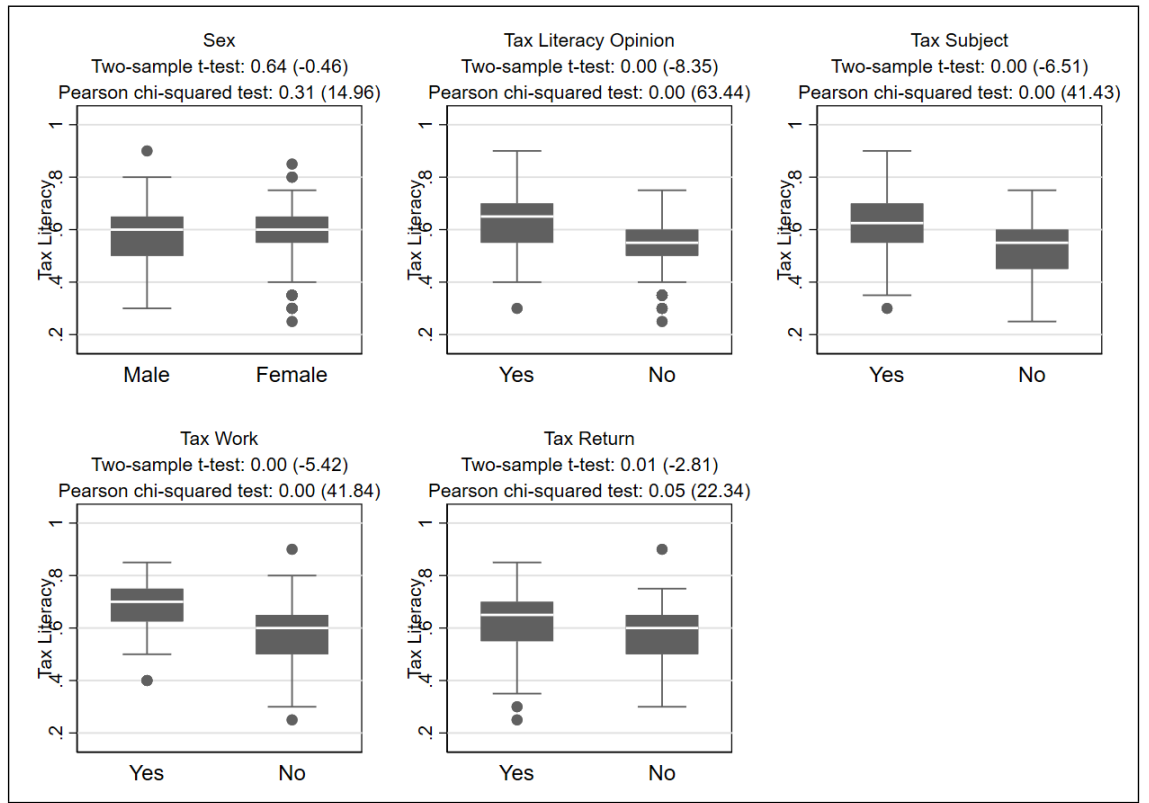

Legend: Tax Literacy (percentage of success in the test); Two-sample t test with equal variance: p-value (t-statistics); Pearson's chi-squared test: p-value (Chi squared). The boxplots include median (white line), the first and the third quartile (lower and upper hinge), lower and upper 1.5 times the interquartile range (whiskers) and extreme outliers (dots).

Source: own work

In the second part we focus on the results of the regression analysis. In the case of the whole set of respondents, we can conclude that the statistical significance for the individual factors is consistent with the results of the statistical tests performed, but with one exception, the effect of tax filing experience is insignificant. If we were to quantify these results, we conclude that tax literacy, measured as a test score, is five percentage points higher for full-time students if the student has taken a tax course or has work experience in accounting or taxation. In the case of the perception of own tax level, the results are better by less than seven percentage points. If we divide the sample of respondents by each year of students of bachelor study programmes, then two basic findings can be made. First, the only statistically significant factors across years of study remain personal perceptions of the level of tax literacy and completion of a tax course, while work experience becomes insignificant. Second, taking a tax course or group of courses has a similar effect on higher levels of tax literacy (by four to six percentage points) across years of students of bachelor study programmes. We add to the comparison across years of study that the results are significantly skewed in the case of extending students, which is probably due to the small number of observations. 
Table 2: Impact of individual factors on the level of tax literacy of respondents

\begin{tabular}{|l|ccccc|}
\hline Tax Literacy & Full file & First year & Second year & Third year & Extending \\
\hline Sex & 0.008 & 0.009 & $\mathbf{- 0 . 0 8 1 * *}$ & 0.035 & 0.028 \\
& $(0.61)$ & $(0.38)$ & $\mathbf{( - 2 . 5 0 )}$ & $(1.61)$ & $(0.75)$ \\
\hline TaxLiteracyOpinion & $\mathbf{0 . 0 6 9} * * *$ & $\mathbf{0 . 0 5 3} * *$ & 0.029 & $\mathbf{0 . 1 0 9 * * *}$ & $\mathbf{0 . 1 4 2} *$ \\
& $\mathbf{( 5 . 1 3 )}$ & $\mathbf{( 2 . 3 3 )}$ & $(1.12)$ & $\mathbf{( 4 . 5 3 )}$ & $(\mathbf{1 . 7 8 )}$ \\
\hline TaxSubject & $\mathbf{0 . 0 5 2} * * *$ & $\mathbf{0 . 0 4 1} *$ & $\mathbf{0 . 0 6 1} * *$ & $\mathbf{0 . 0 5 6} * *$ & 0.006 \\
& $\mathbf{( 3 . 8 3 )}$ & $\mathbf{( 1 . 8 7 )}$ & $\mathbf{( 2 . 1 6 )}$ & $\mathbf{( 2 . 3 0 )}$ & $(0.07)$ \\
\hline TaxWork & $\mathbf{0 . 0 5} * * *$ & $\mathbf{0 . 1 2} * * *$ & 0.031 & 0.022 & 0.038 \\
& $\mathbf{( 3 . 0 6 )}$ & $\mathbf{( 3 . 2 7 )}$ & $(0.87)$ & $(0.86)$ & $(1.01)$ \\
\hline TaxReturn & -0.003 & 0.013 & -0.037 & 0.001 & -0.011 \\
& $(-0.26)$ & $(0.60)$ & $(-1.54)$ & $(0.03)$ & $(-0.19)$ \\
\hline Constant & $\mathbf{0 . 5 0 6 * * *}$ & $\mathbf{0 . 5 0 1} * * *$ & $\mathbf{0 . 5 4 9} * * *$ & $\mathbf{0 . 4 7 4} * * *$ & $\mathbf{0 . 5 1 9} * * *$ \\
& $(\mathbf{4 0 . 7 6 )}$ & $(\mathbf{2 8 . 7 6 )}$ & $(\mathbf{2 0 . 8 5 )}$ & $(\mathbf{1 8 . 9 1 )}$ & $(\mathbf{5 . 3 6 )}$ \\
\hline \hline R ${ }^{2}$ adj. & 0.26 & 0.26 & 0.15 & 0.33 & 0.23 \\
Observations & 283 & 89 & 82 & 93 & 19 \\
B-P/C-W test & 0.11 & 0.4 & 0.89 & 0.07 & 0.49 \\
& $(2.49)$ & $(0.71)$ & $(0.02)$ & $(3.39)$ & $(0.47)$ \\
\hline
\end{tabular}

Legend: (.) denotes t-statistic, $* / * * / * * *$ means a significance level at $10 \% / 5 \% / 1 \% ; \mathrm{R}^{2}$ adj. means an adjusted R-squared; B-P/C-W test means Breusch-Pagan/Cook-Weisberg test for heteroskedasticity, p-value (chi-squared).

Source: own calculation

\section{Discussion}

The research survey showed that the sample of respondents shows good results in terms of tax literacy. The value of the average respondent's score was $59 \%$ and the most common value of the study population was $65 \%$. These results can be assessed as satisfactory, as our results do not confirm the findings of Blechová and Sobotovičová (2013), who, like our authors, focused on students of economically oriented universities. The obtained results may thus point to an improving trend in the level of teaching of tax subjects at economically oriented universities or to the awareness of students that tax issues are an important area that, as graduates of economic universities, will accompany them in their future personal and professional life. A certain limitation, however, may be the voluntariness of participation in the research investigation and therefore the assumption that the research involved students who are interested in tax issues. The authors are also fully aware that the research by Blechová and Sobotovičová (2013) was conducted on a different set of test questions. In addition to identifying the level of tax literacy of the selected segment, factors that may influence the level of tax literacy were analysed as in the case of the authors mentioned in the literature review. The comparison of our results 
with the findings of other authors will start with the factor of gender (Hypothesis 1). In our investigation, gender was found to have no effect on the level of tax literacy of the respondent. These results are inconsistent with the findings of Fallan (1999), who reports that higher levels of tax literacy were identified among men. We then examined whether the level of tax literacy is influenced by how tax literate respondents perceive themselves to be (Hypothesis 2). It was found that the respondent who identified himself as tax literate in the introduction scored higher on the knowledge test. These results are in line with the findings of Paseková, Kovař́k and Ředinová (2013), who also confirm the fact that the respondent's perception of tax literacy has an impact on the outcome of the level of tax literacy. In addition, the authors point to the fact that respondents are capable of objectively assessing their knowledge. However, the most significant factor influencing the level of tax literacy was identified as the effect of taking a tax course during bachelor study programmes (Hypothesis 3). As in Eriksen and Fallan (1996), Palil and Mustapha (2011), Blechová and Sobotovičová (2013), Moučková and Vítek (2018) or Kurniawan (2020), this factor was found to have a significant positive effect on the respondent's level of tax literacy. The importance of this factor is confirmed by the fact that the year of study of the respondent does not play a role in this factor, as the higher level of tax literacy in each year ranged from 4 to 6 percentage points, which can be considered as a significant factor that is stable in relation to the other results. As part of Hypothesis 4, we examined whether respondents' work experience in accounting and taxation has a positive effect on their level of tax literacy. A positive relationship was found for the entire sample, but after dividing the sample by year of study, this factor became insignificant. Therefore, it cannot be clearly confirmed whether this factor has a significant effect on the level of tax literacy. Compared to the results of Sobotovičová and Blechová (2015), we therefore obtain different results, which may be due to the fact that in our research, students of the combined form of study were excluded from the survey due to insufficient number of responses. For the tax filing experience factor, we were unable to confirm the hypothesis that experience can positively influence higher levels of tax literacy (Hypothesis 5). These results are therefore not consistent with the findings of Moučková and Vítek (2018). However, it should be noted that these authors analysed the area of personal income tax and value added tax separately, while our authors analysed the level of tax literacy as a whole.

\section{Conclusion}

As part of the initial investigation of the issue of the level of tax literacy, the author's team selected a group of students of bachelor study programmes at economically oriented universities. The aim of the paper was to identify the factors that influence the level of tax literacy of this group of respondents. In order to meet this objective, a questionnaire survey was first carried out to identify the level of tax literacy and then the data was evaluated using statistical methods and regression analysis. The questionnaire survey involved a total of 283 respondents whose characteristic feature is the full-time form of study. Students of the combined form of study were excluded from the survey due to the insignificant number of respondents involved. 
Based on the results obtained, the most frequently occurring success score was $65 \%$. Subsequently, hypotheses were verified to identify those factors that have a significant positive effect on the level of tax literacy of the respondent. Based on the results obtained, it can be concluded that the gender of the respondent does not affect his/her tax knowledge (Hypothesis 1). The same conclusion was reached for the factor of tax filing experience (Hypothesis 5). For respondents who had work experience in tax and accounting (Hypothesis 4), this factor was significant only for the whole sample, but not when the respondents were stratified by their year of study. Therefore, it can be assumed that this factor does not have a significant effect on full-time students, since even if students are employed in these fields, they usually do only administrative or assistant work. Conversely, the highly significant factors that emerged as significant in relation to the respondent's level of tax literacy include having taken a tax course (Hypothesis 3 ) and perceived tax literacy (Hypothesis 2). The results showed that if a respondent takes a tax course during his/her bachelor study programmes, his/her level of tax literacy is 5 percentage points higher than if he/she does not take the course. In the case of perceptions of one's own level of tax literacy, the results are better by about 7 percentage points.

Therefore, the pilot research survey shows that the level of tax literacy has a very significant impact on the level of tax literacy. In the opinion of the authors' collective, as well as Kasipillai, Aripin and Amran (2003) or Berhane (2011), it is necessary to include tax subjects in the educational process. In relation to the segment of respondents involved in the survey, it is clear that it was tax education that contributed significantly to the satisfactory tax literacy results of the respondents. However, it should be noted that the selected segment consisted of students of bachelor study programmes at economically oriented universities. For this reason, these students take tax courses as part of their compulsory courses. The aim of the authors' team is to conduct further research studies among other segments, such as students of all bachelor study programmes, secondary school students or self-employed persons, especially due to the ever-increasing pressure on the digitalisation of the public administration, spurred by the extent of the COVID-19 pandemic. According to the authors, the topic of tax literacy is a very important area that should be addressed for several reasons. Firstly, if we look at the citizens' side, i.e. taxpayers, we have to say that every citizen will encounter tax issues in his or her life. It would be a mistake to think that medical, technical or agricultural graduates will not face taxes. These and other graduates will be employees or entrepreneurs in their professional life and will deal with tax issues on a daily basis. It is just a question of whether they will deal with the issues on their own or use the services of consultancy firms. Whichever journey they choose, it is important to remember that every journey comes at a cost, whether it is their time spent understanding the tax system or the sums of money they will pay to external bodies. Furthermore, it should be noted that every citizen should be aware of his/her rights and obligations in relation to the fulfilment of tax obligations. It is a mistake to think that a tax advisor will solve my taxes for me, in many cases the tax advisor only prepares the documents prepared by the client. The fact that a citizen does not know what items can be claimed as non-taxable amounts, deductible items or tax credits is to the detriment of the taxpayer. Second, every state should aim to raise the level of tax 
literacy of its citizens for several reasons. Firstly, there is increasing pressure to digitise the civil service, which will only be possible if the population is sufficiently prepared for the transition. Furthermore, if citizens understand the meaning and importance of taxes, their tax morale is positively affected, as confirmed by Eriksen and Fallan (1996).

To conclude this paper, it is worth mentioning that tax literacy is a topic that should certainly be addressed not only at the level of the state, which should create conditions for increasing the level of tax literacy of its citizens, but also by professionals. The present time therefore offers room for reform of the Czech education system so that it meets the criteria stated by Bertl (2016), i.e. that it is set up to best prepare individuals for the conditions of the contemporary world.

\section{Acknowledgments}

Supported by the Internal Grant Agency PEF MENDELU [PEF_TP_2021001].

\section{References}

Alexander, P., Balavac, M., Mukherjee, S, Lymer, A. and Massey, D. (2018). Improving tax literacy and tax morale of young adults. Retrieved May 19, 2020, from https://pdfs.semanticscholar.org/994a/a7f0c9341f53d4aeb6a410cd5bb0e395ab80.pdf?_ga=2.54872043. 1504346601.1590572535-1288475571.1588096475.

Andrlík, B. (2015). Corporation income tax and administrative costs of the public sector. Acta Universitatis Agriculturae et Silviculturae Mendelianae Brunensis, 63(1), 165-173. Available at http://dx.doi.org/10.11118/actaun201563010165.

Bahari, A. B. M. and Ling, L. M. (2009). Introducing tax education in non-accounting curriculum in higher education: Survey evidence. Journal of Financial Reporting and Accounting, 7(1), 37-51. Available at https://doi.org/10.1108/19852510980000640.

Berhane, Z. (2011). The influence of tax education on tax compliance attitude. Retrieved January 1, 2021, from http://213.55.95.56/bitstream/handle/123456789/5781/Zelalem\%20 Berhane.pdf?sequence $=1 \&$ isAllowed $=\mathrm{y}$.

Bertl, I. (2016). Finanční gramotnost v kontextu rozvoje celoživotního učení dospělých: Andragogické, metodické a psychologické souvislosti. Praha: Česká andragogická společnost.

Bhushan, P. and Medury, Y. (2013). Determining tax literacy of salaried individuals - an empirical analysis. IOSR Journal of Business and Management, 10(6), 67-71.

Blechová, B. and Sobotovičová, Š. (2013). Daňová vzdělanost jako součást finanční gramotnosti. Trendy ekonomiky a managementu, 7(14), 17-24.

Bornman, M. and Wassermann, M. (2018). Tax Literacy in the Digital Economy. Retrieved May 20, 2020, from https://www.business.unsw.edu.au/About-Site/Schools-Site/Taxation -Business-Law-Site/Documents/Wassermann_Bornman_eJTR_Tax-literacy-in-the-digital-economy.pdf. 
Bornman, M. and Wassermann, M. (2020). Tax Knowledge for the digital economy. Journal of Economic and Financial Sciences, 13(1), 1-11. Available at https://doi.org/10. 4102/jef.v13i1.461.

Česká školní inspekce (2014). Mezinárodní šetření PISA 2012: Finanční gramotnost patnáctiletých žáků. Retrieved December 7, 2020, from http://www.csicr.cz/html/PISA-FG/ resources/_pdfs_/Zprava_PISA_financni_gramotnost_.pdf.

Cvrlje, D. (2015). Tax literacy as an instrument of combating and overcoming tax complexity, low tax morale and tax non-compliance. The Macrotheme Review, 4(3), 156-167.

Doležalová, J. (2005). Funkční gramotnost - proměny a faktory gramotnosti ve vztazích a souvislostech. Hradec Králové: Gaudeamus.

Eriksen, K. and Fallan, L. (1996). Tax knowledge and attitudes towards taxation: A report on a quasi experiment. Journal of Economic Psychology, 17(3), 387-402. Available at http://dx.doi.org/10.1016/0167-4870(96)00015-3.

Fallan, L. (1999). Gender, exposure to tax knowledge, and attitudes towards taxation: An experimental approach. Journal of Business Ethics, 18(2), 173-184. Available at https://doi.org/10.1023/A:1005711905297.

Gavora, P. (2002). Gramotnost: Vývin modelov, reflexia praxe a výskumu. Pedagogika, 2, 171-181.

GOV.UK (2020). Overview of Making Tax Digital. Retrieved May 27, 2020, from https://www.gov.uk/government/publications/making-tax-digital/overview-of-makingtax-digital.

Halim, H. A., Ahmad, N. L, Katmun, N. and Jaafar, H. (2015). Understanding and Attitudes towards Self-Assessment Taxation System: The Case of Malaysian Non-Accounting Undergraduates Students. Global Review of Accounting and Finance, 6(2), 110-122.

Kasipillai, J., Aripin, N. and Amran, N. A. (2003). The influence of education on tax avoidance and evasion. eJournal of Tax Research, 1(2) 134-146.

Kolbenhayerová, K. and Kř́žová T. (2021). Digitalization of Czech Republic administration and its effects not only on tax administration. Financial Law Review, 21(1), 31-46. Kurniawan, D. (2020). Tax influence of tax education in higher education on tax knowledge and its effect on personal tax compliance. Journal of Indonesian Economy and Business, 35(1), 57-72. Available at https://doi.org/10.22146/jieb.54292.

Latiff, A., Noordin, B., Omar, M. and Harjito, D. (2005). Tax literacy rate among taxpayers: Evidence from Malaysia. Jurnal Akuntansi Dan Auditing Indonesia, 9(1), 1-13.

MFČR (2014). Ministerstvo financí podporuje finanční vzdělávání. Retrieved January 2, 2021, from https://www.mfcr.cz/cs/aktualne/v-mediich/2014/ministerstvo-financi-podporuje-financni-19275.

MFČR (2020). Národní strategie finančního vzdělávání 2.0. Retrieved January 20, 2021, from https://financnigramotnost.mfcr.cz/cs/pro-odborniky/strategicke-dokumenty\#strategie-2.0.

Moučková, M. and Vítek, L. (2018). Tax literacy. Acta Universitatis Agriculturae et Silviculturae Mendelianae Brunensis, 67(2), 553-559. Available at http://dx.doi.org/10.11118/ actaun201866020553. 
Noveský, I. and Balabán, Z. (2009). Slabikář finanční gramotnosti: učebnice základních 7 moduli finanční gramotnosti. Praha: COFET.

OECD (2015). Building tax culture, compliance and citizenship: A global source book on taxpayer education. Retrieved January 10, 2021, from https://doi.org/10.1787/9789264205154-en.

Palil, M. R. and Mustapha, A. F. (2011). Factors affecting tax compliance behaviour in self assessment system. African Journal of Business Management, 5(33), 12864-12872. Available at https://doi.org/10.5897/AJBM11.1742.

Paseková, M., Kovařík, M. and Ředinová, H. (2013). Tax literacy among students of non-economics faculties at Tomas Bata University. ECON-Journal of Economics, 23(1), 39-48. Available at https://doi.org/110.7327/econ.2013.01.04.

Pavelková, J., Knaifl, O. and Preuss, K. (2012). Funkční a finanční gramotnost. Speciální pedagogika: časopis pro teorii a praxi speciální pedagogiky, 22(2), 108-119.

Průcha, J., Walterová, E. and Mareš, J. (2013). Pedagogický slovník. Praha: Portál. Rabušicová, M. (2002). Gramotnost: Staré téma v novém pohledu. Brno: Georgetown. Sobotovičová, Š. and Blechová, B. (2015). Aspekty úrovně daňové vzdělanosti vysokoškolských studentů. Acta academica karviniensia, 15(3), 80-88. Available at https://doi. org/10.25142/aak.2015.033. 